\title{
PENGARUH CURRENT RATIO, RETURN ON ASSET, RETURN ON EQUITY, DEBT TO EQUITY RATIO, TOTAL TURNOVER ASSET, DAN DIVIDEND POLICY TERHADAP HARGA SAHAM
}

\author{
Margaret Calista \\ Program Studi Magister Manajemen Universitas Tarumanagara \\ margaret.calista@gmail.com \\ Indra Widjaja \\ Program Studi Magister Manajemen Universitas Tarumanagara
}

\begin{abstract}
This study aims to analyze factors that affect the stock price that are listed in BEI within a period between year 2012 to 2015 . This research is a study to determine the influence between Current Ratio, Return on Asset, Return on Equity, Debt to Equity Ratio, Total Turnover Asset, and Dividend Policy towards stock price. The population used in this research are all manufacture companies that are listed in BEI during the research period. The samples are collected by using the purposive sampling method. This research used multiple linear regression, with t-statistic test, F-statistic test, and adjusted coefficient of determination to determine the truth about hypotheses. The result of this research are Return on Equity has significant effect on the stock price, while Current Ratio, Return on Asset, Debt to Equity Ratio, Total Turnover Asset, and Dividend Policy has non-significant effect on the stock price. Together, Current Ratio, Return on Asset, Return on Equity, Debt to Equity Ratio, Total Turnover Asset, and dividend policy have significant effect on stock price.
\end{abstract}

Abstrak : Penelitian ini bertujuan untuk menganalisa faktor-faktor yang mempengaruhi harga saham di BEI dalam periode tahun 2012 hingga 2015. Penelitian ini digunakan untuk mengetahui pengaruh antara Current Ratio, Return on Asset, Return on Equity, Debt to Equity Ratio, Total Turnover Asset, dan Dividend Policy terhadap harga saham. Populasi dalam penelitian ini merupakan seluruh perusahaan manufaktur yang terdapat di BEI selama periode penelitian. Sampel dikumpulkan dengan menggunakan teknik purposive sampling. Penelitian ini menggunakan regresi linear berganda, dengan uji-t, uji-F, dan koefisien determinasi untuk menentukan kebenaran dari hipotesis. Hasil dari penelitian ini adalah Return on Equity memiliki pengaruh signifikan terhadap harga saham, Current Ratio, Return on Asset, Debt to Equity Ratio, Total Turnover Asset, dan Dividend Policy Asset memiliki pengaruh tidak signifikan terhadap harga saham. Secara bersama-sama, Current Ratio, Return on Asset, Return on Equity, Debt to Equity Ratio, Total Turnover Asset, dan Dividend Policy memiliki pengaruh signifikan terhadap harga saham.

Keywords : Current Ratio, Return on Asset, Return on Equity, Debt to Equity Ratio, Total Turnover Asset, Dividend Policy, Stock Price

\section{Latar Belakang}

Pada era globalisasi ini, keadaan perekonomian semakin tidak stabil. Ketidakstabilan perekonomian ini dapat memberikan manfaat tetapi juga dapat memberikan kerugian bagi masyarakat maupun perusahaan pelaku investasi (Adipalguna,S.,Suarjaya,A.A.G.,2016).

Kinerja keuangan perusahaan merupakan salah satu faktor yang dilihat investor untuk menentukan dalam membeli saham. Untuk menilai kinerja keuangan perusahaan diperlukan rasio-rasio keuangan (Kurniawan, Angga, 2017).

Kebijakan pembayaran dividen mempunyai pengaruh bagi pemegang saham dan perusahaan yang membayar dividen. Bagi perusahaan, pilihan untuk membagikan laba dalam 
bentuk deviden akan mengurangi sumber dana internalnya, sebaliknya jika perusahaan menahan labanya dalam bentuk laba ditahan maka kemampuan pembentukan dana internalnya akan semakin besar yang dapat digunakan untuk membiayai aktivitas perusahaan sehingga mengurangi ketergantungan perusahaan terhadap dana eksternal dan sekaligus akan memperkecil resiko perusahaan.

Berdasarkan latar belakang diatas, maka peneliti tertarik untuk melakukan penelitian mengenai "Pengaruh Current ratio, Return on Asset, Return on Equity, Debt to Equity Ratio, Total Turnover Asset, dan Dividend Policy terhadap Harga Saham".

\section{Tujuan Penelitian}

Berdasarkan perumusan masalah yang telah diuraiakan, maka tujuan dari penelitian ini adalah untuk mengetahui (a) Pengaruh Current Ratio terhadap Harga Saham, (b) Pengaruh Return on Asset terhadap Harga Saham, (c) Pengaruh Return on Equity terhadap Harga Saham (d) Pengaruh Debt to Equity Ratio terhadap Harga Saham, (e) Pengaruh Total Turnover terhadap Harga Saham, (f) Pengaruh Dividend Policy terhadap Harga Saham.

\section{Tinjauan Pustaka}

a. Saham

Saham adalah surat berharga yang diperdagangkan di pasar modal yang dikeluarkan oleh sebuah perusahaan yang berbentuk Perseroan Terbatas (PT) (Tandelilin, 2010,p18). Faktorfaktor yang berpengaruh terhadap harga saham dapat dibagi menjadi tiga, yaitu: (1) Faktor yang bersifat fundamental. Faktor yang memberikan informasi tentang kinerja perusahaan dan faktor-faktor lain yang dapat mempengaruhinya. (2) Faktor yang bersifat teknis. Faktor teknis menyajikan informasi yang menggambarkan pasaran suatu efek baik secara individu maupun secara kelompok. (3) Faktor sosial dan politik: 1. Tingkat inflasi yang terjadi, 2. Kebijaksanaan moneter yang dilakukan oleh pemerintah, 3. Kondisi perekonomian, 4. Keadaan politik suatu Negara.

\section{b. Kinerja Keuangan}

Rasio keuangan merupakan metode umum yang digunakan untuk mengukur kinerja perusahaan di bidang keuangan (Dahlan, 2005, p53). Adapun jenis rasio menurut (Dahlan, 2005, p53) yaitu (1) Rasio Profitabilitas. Rasio profitabilitas adalah rasio yang mengukur seberapa besar kemampuan perusahaan dalam menghasilkan keuntungan. (2) Rasio Leverage. Rasio leverage atau rasio solvabilitas adalah rasio yang mengukur kemampuan perusahaan dalam memenuhi kewajiban-kewajiban jangka panjangnya. (3) Rasio Likuiditas. Rasio likuiditas adalah rasio yang mengukur kemampuan suatu perusahaan memenuhi kewajiban jangka pendeknya. (4) Rasio Aktivitas. Rasio aktivitas adalah rasio yang mengukur bagaimana perusahaan secara efektif mengelola aktiva-aktivanya.

\section{c. Kebijakan Deviden}

Dividen adalah distribusi kepada pemegang saham suatu perusahaan secara proporsional dengan jumlah saham yang dimiliki oleh masing-masing pemegang saham (Danica, Clara \& Marlina, Lisa, 2009). Ada dua rasio yang dapat digunakan untuk mengukur kebijakan dividen. Yang pertama adalah dividend yield ratio, yaitu rasio imbal hasil dividen yang menunjukkan tingkat penghasilan yang diperoleh dari investasi perusahaan.

Rasio kedua adalah rasio pembayaran dividen (dividend payout ratio). Rasio ini merupakan rasio yang paling penting diperhatikan dalam penentukan kebijkan dividen perusahaan. Dividend payout ratio (DPR) merupakan proporsi laba bersih yang dibagikan secara kas kepada pemegang saham. Rasio ini adalah perbandingan antara dividen yang dibagikan dengan laba bersih yang diperoleh perusahaan, biasanya disajikan dalam bentuk presentase (Sitanggang, 2012 dalam Marlina.L. \& Danica.C, 2009). 


\section{Hipotesis Pemikiran}

Berdasarkan teori yang telah diuraikan di atas, maka akan diuji apakah variabel Current Ratio, Return on Asset, Return on Equity, Debt to Equity Ratio,Total Turnover, dan Dividend Policy berpengaruh terhadap harga saham perusahaan properti yang terdaftar di BEI. Metode penelitian dalam penelitian ini adalah sebagai berikut :

Kerangka pemikiran

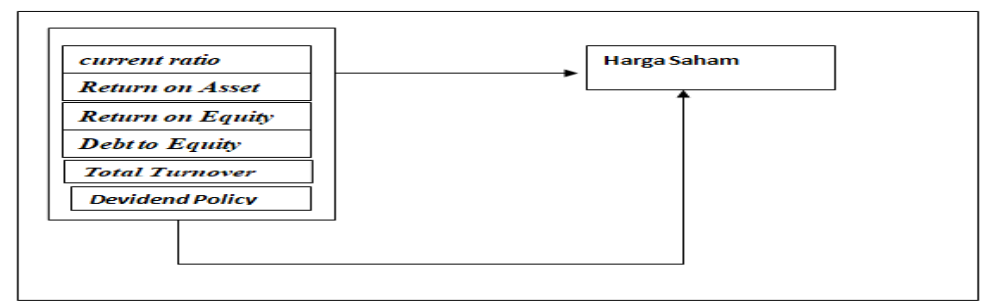

Dalam penelitian ini terdapat enam hipotesis yang diuji, yaitu :

1. Ha1 : Terdapat pengaruh signifikan antara Current Ratio dengan Harga Saham.

2. Ha2 : Terdapat pengaruh signifikan antara Return on Asset dengan Harga Saham.

3. Ha3 : Terdapat pengaruh signifikan antara Return on Equity dengan Harga Saham.

4. Ha4 : Terdapat pengaruh signifikan antara Debt to Equity dengan Harga Saham.

5. Ha5 : Terdapat pengaruh signifikan antara Total Turn Over dengan Harga Saham.

6. Ha6 : Terdapat pengaruh signifikan antara Dividend policy dengan Harga Saham.

\section{Metodologi Penelitian}

Jenis data yang digunakan dalam penelitian ini adalah data sekunder, yaitu harga saham, current ratio, Return on Asset, Return on Equity, Debt to Equity Ratio, Total Turnover, dan dividend policy. Populasi penelitian ini adalah perusahaan properti yang terdaftar di BEI untuk tahun 2012, 2013, 2014, dan 2015. Sampel dipilih secara purposive sampling dengan kriteria sebagai berikut: (1) Perusahaan tercatat dalam Bursa Efek Indonesia (BEI). (2) Perusahaan merupakan perusahaan manufaktur yang terdaftar di BEI periode 2012-2015. (3)Perusahaan merupakan perusahaan yang menerbitkan laporan keuangan tahunan yang berakhir pada tanggal 31 Desember selama periode pengamatan 2012-2015. (4) Laporan keuangan disajikan dalam rupiah. (5) Perusahaan memiliki data pasar dan data keuangan lengkap. (6) Menghasilkan laba selama periode penelitian. (7) Memiliki data yang lengkap terkait dengan varibel variabel yang digunakan dalam penelitian.

\section{Hasil Penelitian}

Sebelum dilakukan analisis, data yang telah dikumpulkan harus diuji terlebih dahulu agar mendapat hasil yang lebih efisien.

1. Uji Multikolinearitas

\begin{tabular}{|l|r|r|r|r|r|r|}
\hline & \multicolumn{1}{l|}{ LCR } & LDER & LDPR & LROA & LROE & LTATO \\
\hline LCR & 1 & $-0,54627$ & $-0,26001$ & 0,114097 & $-0,05059$ & 0,20161 \\
\hline LDER & $-0,54627$ & 1 & 0,239157 & $-0,13647$ & 0,568604 & $-0,13742$ \\
\hline LDPR & $-0,26001$ & 0,239157 & 1 & $-0,06345$ & 0,138527 & 0,09561 \\
\hline ROA & 0,114097 & $-0,13647$ & $-0,06345$ & 1 & 0,525957 & 0,184636 \\
\hline LROE & $-0,05059$ & 0,568604 & 0,138527 & 0,525957 & 1 & 0,173031 \\
\hline LTATO & 0,20161 & $-0,13742$ & 0,09561 & 0,184636 & 0,173031 & 1 \\
\hline
\end{tabular}

Berdasarkan tabel diatas, variabel CR, ROA, ROE, DER, TATO dan DPR memiliki nilai lebih kecil dari 0,8. Artinya, dengan tingkat keyakinan 95\%, tidak terdapat multikolinearitas pada data.

2. Uji Autokorelasi

Durbin-Watson stat

1.887039 
Dari hasil tabel di atas, dapat disimpulkan bahwa angka D-W terletak diantara -2 sampai +2 sehingga dapat disimpulkan dalam model regresi tidak terdapat autokorelasi

3. Uji Heteroskedastisitas

\begin{tabular}{crrrc}
\hline \hline Variable & Coefficient & Std. Error & t-Statistic & Prob. \\
\hline \hline LCR & -0.293528 & 0.203314 & -1.443720 & 0.1562 \\
LDER & -0.234407 & 0.124230 & -1.886881 & 0.0661 \\
LDPR & 0.124616 & 0.078451 & 1.588458 & 0.1197 \\
LROA & -0.130257 & 0.116067 & -1.122255 & 0.2681 \\
LROE & 0.246207 & 0.136738 & 1.800576 & 0.0790 \\
LTATO & -0.017573 & 0.016291 & -1.078698 & 0.2869 \\
C & 0.751683 & 0.290185 & 2.590359 & 0.0131 \\
\hline \hline
\end{tabular}

Hasil probabilitas masing-masing variabel $>0.05$. Hal ini menunjukkan bahwa dengan tingkat keyakinan $95 \%$ tidak terdapat hasil heteroskedastisitas.

4. Uji Normalitas

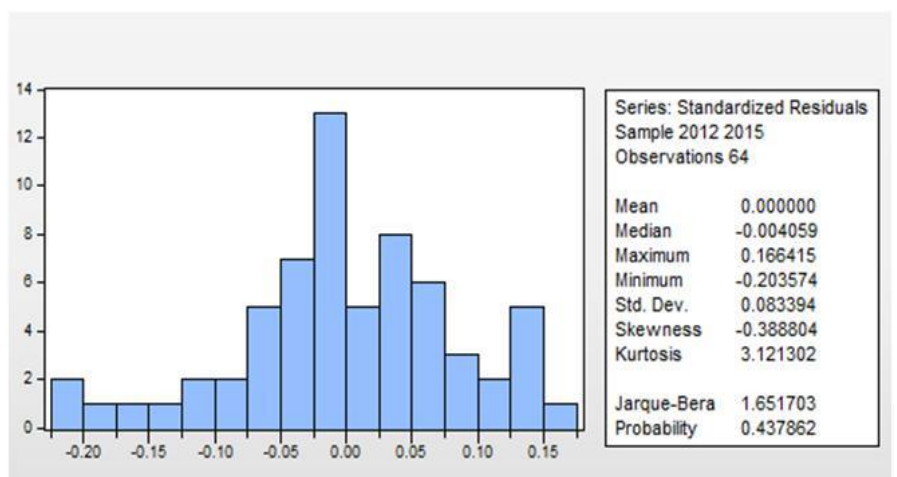

Dari hasil tabel diatas, maka didapat hasil probabilitas sebesar $0.44>0.05$. Maka dapat ditarik kesimpulan bahwa dengan tingkat keyakinan 95\% residual data terdistribusi secara normal.

\section{Uji Regresi Berganda}

Untuk mengetahui pengaruh variabel-variabel tersebut, maka dilakukan uji regresi menggunakan Eviews 8.0. Berikut adalah tabel hasil pengujian tersebut:

\begin{tabular}{|c|c|c|c|c|}
\hline \multicolumn{5}{|c|}{$\begin{array}{l}\text { Dependent Variable: LHARGA } \\
\text { Method: Panel Least Squares } \\
\text { Date: } 02 / 23 / 19 \text { Time: } 16: 22 \\
\text { Sample: } 20122015 \\
\text { Periods included: } 4 \\
\text { Cross-sections included: } 16 \\
\text { Total panel (balanced) observations: } 64\end{array}$} \\
\hline Variable & Coefficient & Std. Error & t-Statistic & Prob. \\
\hline LCR & -0.205748 & 0.136661 & -1.505536 & 0.1397 \\
\hline LDER & -0.091691 & 0.083503 & -1.098054 & 0.2784 \\
\hline LDPR & 0.020539 & 0.052732 & 0.389491 & 0.6989 \\
\hline LROA & -0.069188 & 0.078016 & -0.886835 & 0.3802 \\
\hline LROE & 0.201066 & 0.091911 & 2.187617 & 0.0343 \\
\hline LTATO & -0.014207 & 0.010950 & -1.297458 & 0.2016 \\
\hline $\mathrm{c}$ & 4.565506 & 0.195053 & 23.40648 & 0.0000 \\
\hline \multicolumn{5}{|c|}{ Effects Specification } \\
\hline \multicolumn{5}{|c|}{ Cross-section fixed (dummy variables) } \\
\hline & & \multirow{6}{*}{\multicolumn{2}{|c|}{$\begin{array}{l}\text { Mean dependent var } \\
\text { S.D. dependent var } \\
\text { Akaike info criterion } \\
\text { Schwarz criterion } \\
\text { Hannan-Quinn criter. } \\
\text { Durbin-Watson stat }\end{array}$}} & \\
\hline Adjusted R-squared & 0.963075 & & & 0.531517 \\
\hline S.E. of reg & 0.102136 & & & -1.458737 \\
\hline Sum squared re & 0.438134 & & & -0.716621 \\
\hline Log likelinood & 68.67960 & & & -1.166380 \\
\hline F-statistic & 79.24536 & & & 1.887039 \\
\hline Prob(F-statistic) & 0.000000 & & \\
\hline
\end{tabular}

Berdasarkan tabel di atas, maka dapat disimpulkan bahwa.

\section{a. Hipotesis 1}

Probabilitas current ratio (CR) terhadap saham pada adalah 0.13 . Karena probabilitas CR lebih besar daripada nilai signifikansi signifikansi $(\alpha)$ sebesar 5\%, maka hipotesis 1 diterima. Artinya, tidak terdapat pengaruh signifikan antara CR terhadap harga saham secara parsial. Hal ini dapat disebabkan karena investor cenderung melihat atau lebih mempertimbangkan rasio lain dalam pengambilan keputusan berinvestasi saham (Widayanti.R, 2016). 


\section{b. Hipotesis 2}

Probabilitas Return on Asset (ROA) terhadap saham adalah 0.38. Karena probabilitas ROA lebih besar daripada nilai signifikansi signifikansi $(\alpha)$ sebesar 5\%, maka hipotesis 2 diterima. Artinya, tidak terdapat pengaruh signifikan antara Return on Asset (ROA) terhadap harga saham secara parsial. Walaupun laba yang dihasilkan perusahaan tinggi, tetapi laba yang diperoleh perusahaan akan digunakan untuk membayar kewajiban. (Ahmaddin, 2015 dalam Hutapea,A., Saerang,I.S, Tulung, J.E., 2017)

c. Hipotesis 3

Probabilitas Return on Equity (ROE) terhadap saham adalah 0.03. Karena probabilitas Return on Equity (ROE) lebih kecil daripada nilai signifikansi signifikansi $(\alpha)$ Return on Equity (ROE) bahwa Return on Equity (ROE) memiliki pengaruh terhadap harga saham. Semakin tinggi ROE berarti semakin efisien dan efektif penggunaan ekuitas perusahaan untuk mendapatkan keuntungan bagi pemegang saham.

d. Hipotesis 4

Probabilitas Debt to Equity Ratio (DER) terhadap saham,adalah 0.28. Karena probabilitas Debt to Equity Ratio (DER) lebih besar daripada nilai signifikansi signifikansi $(\alpha)$ sebesar 5\%, maka hipotesis 4 diterima. Artinya, tidak terdapat pengaruh signifikan antara Debt to Equity Ratio (DER) terhadap harga saham secara parsial. Hal ini dapat disebabkan karena investor cenderung melihat atau lebih mempertimbangkan rasio lain dalam pengambilan keputusan berinvestasi saham.

e. Hipotesis 5

Probabilitas Total Turnover Asset (TATO) terhadap saham pada adalah 0.20. Karena probabilitas Total Turnover Asset (TATO) lebih besar daripada nilai signifikansi signifikansi $(\alpha)$ sebesar 5\%, maka hipotesis 5 diterima. Artinya, tidak terdapat pengaruh signifikan antara Total Turnover Asset (TATO) terhadap harga saham secara parsial.

f. Hipotesis 6

Probabilitas Dividend Policy (DPR) terhadap saham adalah 0.69. Karena probabilitas Dividend Policy (DPR) lebih besar daripada nilai signifikansi signifikansi $(\alpha)$ sebesar 5\%, maka hipotesis 6 diterima. Artinya, tidak terdapat pengaruh signifikan antara Dividend Policy (DPR) terhadap harga saham secara parsial.

\section{Kesimpulan}

Dalam penelitian ini terbukti hanya Return On Equity (ROE) yang signifikan terhadap harga saham. Investor dapat melihat nilai Return On Equity (ROE) dalam mengambil keputusan untuk berinvestasi karena variabel tersebut telah terbukti memiliki pengaruh yang positif terhadap harga saham. Salah satu alasan perusahaan dalam beroperasi adalah untuk menghasilkan laba yang akan dinikmati para pemegang saham, sehingga semakin besar Return On Equity (ROE) akan mencerminkan kemampuan perusahaan dalam menghasilkan laba bagi para investor. Sedangkan variabel lainnya yaitu CR, ROA, DER, TATO dan DPR tidak berpengaruh signifikan terhadap harga saham. 


\section{DAFTAR PUSTAKA}

Adipalguna, S. \& Suarjaya, A. (2016). Pengaruh Likuiditas, Solvabilitas, Aktivitas, Profitabilitas, dan Penilaian Pasar Terhadap Harga Saham Perusahaan LQ45 di BEI. E-Jurnal Manajemen Unud, Vol. 5, ISSN : 2302-8912

Brigham, Eugene F., dan Houston, Joel F. (2010). Manajemen Keuangan. Jakarta : Erlangga.

Bailia F., Tommy, P., \& Baramulli, D. Pengaruh Pertumbuhan Penjualan, Dividend Payout Ratio dan Debt To Equity Ratio Terhadap Harga Saham Pada Perusahaan Property Di Bursa Efek Indonesia.

Budialim, G (2016). Analisis Pengaruh EVA dan Rasio- Rasio Profitabilitas terhadap Harga Saham. E-Jurnal Manajemen Unud, Vol. 5, ISSN : 2302-8912

Dahlan. (2005). Manajemen Keuangan Pendekatan Praktis. Diadit Media. Jakarta.

Ghozali, Imam. (2009). Aplikasi Analisis Multivariate dengan Program SPSS. Semarang: Badan penerbit-Undip.

Hutapea, A., Saerang, I., \& Tulung, J., (2017). Pengaruh Return on Assets, Net Profit Margin, Debt to Equity Ratio, dan Total Assets Turnover Terhadap Harga Saham Industri Otomotif dan Komponen yang Terdaftar di Bursa Efek Indonesia, Vol.5, ISSN 23031174

Husnan, S. (2009). Dasar - Dasar Teori Portofolio dan Analisis Sekuritas. Edisi Keempat. Cetakan kedua. UPP STIM YKPM : Yogyakarta.

Jogiyanto, H. M. 2007. Teori Portofolio dan Analisis Investasi. Yogyakarta: BPFE.

Kieso, Donald E., Weygandi, Jerry D., Warfield, Terry D., (2005). Akuntansi Intermediate. Jilid1, Edisi Kesepuluh. Jakarta Erlangga.

Kurniawan, Angga (2017). Board Pengaruh Kinerja Keuangan terhadap Return Saham dengan Menjadikan Kebijakan Dividen sebagai Variabel Moderat pada Perusahaan yang terdaftar di Jakarta Islamic Indeks (JII 2007-2011), akuisisi-vol 13.

Kusumawati.W.S. (2016). Pengaruh Profitabilitas, Kebijakan Dividen dan Risiko Sistematis Terhadap Harga Saham, Jurnal Administrasi Bisnis (JAB)Vol. 35

Nugraha Dewangga, (2016). Analisis Pengaruh DPR, DER, ROE, DAN TATO Terhadap Harga Saham, Volume 5ISSN (Online): 2337-3792

Nugraha, N.A \& Mertha, M. I, (2016). Likuiditas sebagai Pemoderasi Pengaruh profitabilitas dan Struktur Modal pada Return Saham Perusahaan Manufaktur, E- Jurnal Akuntansi Universitas Udayana Vol.15, ISSN: 2302-8556.

Marlina.L. \& Danica.C, (2009). Analisis Pengaruh Cash Position, Debt to Equity Ratio, dan Return on Assets terhadap Dividend Payout Ratio, Jurnal Manajemen Bisnis, Volume 2.

Mudrajad, Kuncoro. (2013). Mudah Memahami dan menganalisis Indikator ekonomi. Yogyakarta : UPP STIM YKPN.

Puspitadewi, C.I.I \& Rahyuda, H, (2016). Analisis Pengaruh DER, ROA, PER dan EVA terhadap Harga Saham pada Perusahaan Food and Beverage di BEI, E-Jurnal Manajemen Unud, Vol. 5, ISSN : 2302-8912.

Santoso, Singgih. (2015), Menguasai Statistik Parametrik - Konsep dan Aplikasi dengan SPSS, Jakarta: PT.Elex Media Komputindo.

Tandelilin, E. (2010). Portofolio dan Investasi-Teori dan Aplikasi. Kasinus. Yogyakarta.

Tamuntuan, Ursula (2015). Analysing the Effect of Return on Equity, Return on Assets and Earnings Per Share Toward Share Price: an Emperical Study of Food and Beverage Companies Listed on Indonesia Stock Exchange, Volume 15 